DOI: $10.33377 /$ jkh.v4i2.85

\title{
PENGETAHUAN, SIKAP DAN KETERAMPILAN MASYARAKAT DALAM PENCEGAHAN COVID-19 DI PROVINSI DKI JAKARTA
}

\author{
Ressa Andriyani Utami ${ }^{1 *}$, Ria Efkelin Mose ${ }^{1)}$, Martini ${ }^{2)}$ \\ ${ }^{1)}$ Sekolah Tinggi Ilmu Kesehatan RS Husada, Jalan Raya Mangga Besar 137-139, \\ Jakarta Pusat, Indonesia \\ ${ }^{2)}$ RS Husada, Jalan Raya Mangga Besar No.137-139, Jakarta Pusat, Indonesia \\ e-mail : ressa.andriyani.utami@gmail.com
}

\begin{abstract}
ABSTRAK
Penyakit virus Corona 2019 (COVID-19) telah ditetapkan sebagai pandemik global oleh WHO, penyakit ini disebabkan oleh SARS-CoV-2. Program penatalaksanaan yang telah dilakukan oleh Pemerintah Indonesia adalah Pembatasan Sosial Berskala Besar (PSBB) dan sekarang adalah Adaptasi Kebiasaan Baru (AKB) atau new normal. Upaya ini dilakukan untuk mengurangi penyebaran COVID-19. Penelitian ini dilakukan untuk mengidentifikasi pengetahuan, sikap, dan perilaku masyarakat provinsi DKI Jakarta terhadap pencegahan penularan SARS-CoV-2. Penelitian ini menggunakan analisis deskriptif, mendistribusikan pertanyaan tertutup dalam kuesioner online secara acak ke 5 Kota di Provinsi DKI Jakarta melalui jaringan media sosial. Responden penelitian ini berjumlah 1021. Data dianalisis menggunakan deskriptif dengan menghitung frekuensi, persentase, dan tabulasi silang. Penelitian menunjukkan $83 \%$ memiliki pengetahuan yang baik, 70,7\% sikap yang baik dan 70,3\% keterampilan yang baik dalam pencegahan COVID 19. Perlu upaya promosi kesehatan dan pemantauan lapangan yang ketat dan masif di masyarakat agar pandemik ini segera berakhir.
\end{abstract}

Kata kunci: Covid 19; Pandemik; Pencegahan; Pengetahuan; Sikap

\begin{abstract}
Corona 2019 virus disease (COVID-19) has been designated as a global pandemic by WHO. This disease is caused by SARS-CoV-2. The management program that has been carried out by the Government of Indonesia is the Large-Scale Social Limitation (PSBB) and now it is the Adaptation of New Habits (AKB) or new normal. This effort was made to reduce the spread of COVID-19. This research was conducted to identify the knowledge, attitudes and behavior of the people of DKI Jakarta province towards the prevention of SARS-CoV-2 transmission. This research uses descriptive analysis, distributing closed questions in a randomized online questionnaire to 5 cities in DKI Jakarta Province through social media networks. The number of respondents in this study was 1021. Data were analyzed using descriptive analysis by calculating frequency, percentage, and cross tabulation. Research shows $83 \%$ have good knowledge, $70.7 \%$ good attitude and $70.3 \%$ good skills in COVID prevention 19. It is necessary to conduct strict and massive health promotion and field monitoring in the community so that this pandemic ends soon.
\end{abstract}

Key words: Covid 19; Pandemic; Prevention; Knowledge; Attitude

Jurnal Kesehatan Holistic/ Volume 4/ Nomor 2/Juli 2020

(ISSN: 2548-1843, EISSN: 2621-8704) 


\section{PENDAHULUAN}

Pandemi COVID-19 muncul ketika virus ini diketahui menyebar dari orang ke orang dalam waktu singkat dan dengan gejala seperti demam tinggi, batuk, sesak, tidak nafsu makan dan lemas. COVID-19 pertama kali dilaporkan di Wuhan, Hubei, Cina pada Desember 2019, dan pada 11 Maret 2020 Organisasi Kesehatan Dunia (WHO) menyatakan bahwa COVID-19 telah menjadi penyakit pandemi di seluruh dunia (Andrews, Foulkes, \& Blakemore, 2020).

Wabah COVID-19 ditetapkan sebagai pandemik global oleh WHO pada 11 Maret 2020, dengan peningkatan 13 kali lipat dalam jumlah kasus yang dilaporkan di luar China, lebih dari beberapa minggu.1 Ini telah mempengaruhi lebih dari 2,3 juta orang di 185 negara di dunia. Dari total beban global, sedikit di atas 120 ribu kasus yang dikonfirmasi dan 5784 kematian dilaporkan di EMRO pada 18 April 2020. KSA, dengan 7142 kasus dan 87 kematian, adalah yang ketiga negara di kawasan yang akan terpengaruh oleh novel coronavirus atau SARS-CoV-2 (sindrom pernafasan akut yang parah) $\mathrm{CoV}-2$ ) Angka fatalitas kasus (CFR) secara keseluruhan di antara semua negara adalah $6,8 \%$, tetapi tertinggi di Italia pada 13,1\%. Pandemi COVID-19 dapat menjadi pandemi kategori 3, tergantung pada nomor reproduksinya (R0) dan keseluruhan rasio fatalitasnya jauh (Mansuri, Zalat, Khan, Alsaedi, \& Ibrahim, 2020). Kasus COVID-19 yang dilaporkan ditemukan di 203 negara di seluruh dunia pada awal April 2020, dengan total 937.976 kasus yang dikonfirmasi dan 47.279 kematian. Pada Bulan April 2020, Indonesia menunjukkan sejumlah besar kasus dan kematian yang dikonfirmasi dalam wabah COVID19, dan diperlukan strategi pencegahan untuk penyebarluasan penyakit yang lebih parah (Yanti et al., 2020).

Kondisi ini diperparah dengan belum adanya metode pengobatan khusus atau vaksin terhadap penyakit coronavirus yang baru sehingga pada situasi seperti itu, intervensi nonfarmasi diutamakan, seperti strategi 
pencegahan oleh masyarakat untuk memperlambat transmisi, khususnya di antara populasi berisiko tinggi (Zhang et al., 2020). Transmisi COVID-19 dapat diperlambat melalui penatalaksanaan social distancing yang benar. Pedoman WHO tentang kesiapsiagaan, kesiapan, dan tindakan respons kritis untuk COVID-19 membahas beberapa strategi yang dapat diterapkan oleh negara-negara untuk memperlambat penyebaran penyakit dan mencegah sistem kesehatan. Penatakalksanaan yang harus diterapkan oleh seluruh masyarakat pada berbagai tatanan adalah menggunakan masker, tidak melakukan kontak fisik, menjaga jarak minimal 2 meter, rajin cuci tangan menggunakan sabun di air mengalir, membawa antiseptik, menggunakan alat makan sendiri, dan tindakan lainnya (Liu et al., 2020).

Tindakan protokol kesehatan yang ditetapkan oleh WHO dan Kementerian Kesehatan RI tidak akan berjalan sebelum masyarakat dibekali dengan pengetahuan, sikap dan keterampilan yang baik dalam pelaksanaannya. Diperlukan adanya sosialisasi dan upaya-upaya promosi kesehatan yang gencar sehingga terdapat perubahan pada kognitif, afektif dan psikomotor masyarakat dalam pencegahan COVID-19 (Saqlain et al., 2020). Pemerintah juga perlu mempublikasikan data yang terbuka, akurat dan komprehensif terkait kondisi penyebaran COVID-19. Data terbuka dari distribusi pandemi dapat meningkatkan kepercayaan publik terhadap pemerintah dan menghasilkan stabilitas masyarakat. Sebaliknya, data yang disembunyikan dari publik justru akan membuat ketidakpercayaan masyarakat dalam mengikuti himbauan pemerintah (Farizi \& Harmawan, 2020). Pemerintah harus sigap dalam melacak area atau zona dengan kasus penularan yang tinggi sehingga proses identifikasi lokasi yang terdampak parah bisa segera ditindaklanjuti baik oleh tenaga medis dan pemerintah (Suryaatmadja \& Maulani, 2020).

Kasus COVID-19 di Indonesia pertama kali diketahui terjadi di Provinsi DKI Jakarta pada Bulan 
Januari 2020. Penelitian ini dilakukan untuk mengatahui bagaimana gambaran pengetahuan, sikap dan keterampilan masyarakat Provinsi DKI Jakarta dalam pencegahan COVID-19. Penelitian ini pentig dilakukan untuk mengetahui langkah strategis selanjutnya yang dapat dilakukan melalui pemberdayaan masyarakat.

\section{METODE}

Penelitian menggunakan metode analisis deskriptif. Populasi pada penelitian ini adalah orang dewasa di Provinsi DKI Jakarta. Data dikumpulkan melalui kuesioner online tidak langsung melalui jaringan media sosial pada 17-30 Juni 2020. Kuisioner ini, menggunakan pertanyaan tertutup dan pilihan ganda, didistribusikan ke 5 Kota di Provinsi DKI Jakarta, yaitu Kota Jakarta Barat, Selatan, Pusat, Timur dan Utara. Jumlah responden yang ikut serta dalam penelitian ini sebanyak 1021 orang. Variabel penelitian ini adalah pengetahuan, sikap, dan perilaku, dan untuk setiap variabel ada 10 item yang terhubung dengan menggunakan protokol new normal sebagai salah satu strategi pengendalian pandemi. Pengetahuan diukur dengan apakah responden dapat mengidentifikasi penyebab penyakit dan penularan, gejala umum, risiko dan pencegahan COVID-19. Sikap diukur sesuai dengan kesadaran akan jarak sosial di tempat kerja dan ibadah, serta belajar dari rumah. Perilaku terkait dengan melakukan kegiatan pencegahan seperti mencuci tangan, menghindari menyentuh wajah, mengikuti etiket batuk dan bersin, memakai masker, dan menggunakan desinfektan untuk mencegah COVID-19.

Kuesioner terdiri dari aspek data demografi, pengetahuan, sikap, dan keterampilan, masing-masing berisi item terkait pencegahan COVID-19. Para responden memberikan informasi tentang usia, tingkat pendidikan, pekerjaan, dan status perkawinan.

Pengukuran pengetahuan dan perilaku menggunakan skala Guttman, dan skala Likert digunakan untuk pengukuran sikap. Data dianalisis dengan analisis deskriptif dengan menghitung distribusi frekuensi dan 
persentase. Penelitian ini telah memenuhi prinsip etik autonomy, beneficence, justice, nonmaleficence, veracity, fidelity, confidentiality dan accountability.

\section{HASIL DAN PEMBAHASAN}

Karakteristik sosiodemografi responden penelitian adalah sebagai berikut:

Tabel 1 Karakteristik Responden

\begin{tabular}{|c|c|c|}
\hline Karakteristik & $\begin{array}{c}\text { Frekuensi } \\
\text { (n) }\end{array}$ & $\begin{array}{c}\text { Persentase } \\
(\%)\end{array}$ \\
\hline \multicolumn{3}{|l|}{ Umur (tahun) } \\
\hline $26-35$ & 448 & 43,9 \\
\hline $36-45$ & 523 & 51,2 \\
\hline $46-65$ & 50 & 4,9 \\
\hline \multicolumn{3}{|l|}{ Jenis kelamin } \\
\hline Laki-laki & 339 & 33,2 \\
\hline Perempuan & 682 & 66,8 \\
\hline \multicolumn{3}{|l|}{ Pendidikan } \\
\hline Tinggi & 674 & 66.0 \\
\hline Rendah & 34 & 44,0 \\
\hline \multicolumn{3}{|l|}{ Pekerjaan } \\
\hline PNS & 178 & 17,4 \\
\hline Wiraswasta & 247 & 24,2 \\
\hline Karyawan & 223 & 21,7 \\
\hline \multicolumn{3}{|l|}{ Swasta } \\
\hline Buruh & 59 & 5,7 \\
\hline IRT & 229 & 22,4 \\
\hline TNI/Polri & 14 & 1,7 \\
\hline Pelajar & 35 & 3,4 \\
\hline Tidak Bekerja & 36 & 3,5 \\
\hline \multicolumn{3}{|l|}{ Status Pernikahan } \\
\hline Menikah & 442 & 43,3 \\
\hline Belum & 386 & 37,8 \\
\hline \multicolumn{3}{|l|}{ Menikah } \\
\hline Janda/Duda & 193 & 18,9 \\
\hline
\end{tabular}

Hasil analisis yang didapatkan pada karakteristik responden adalah 51,2\% responden berusia 36-45 tahun, $66,8 \%$ responden berjenis kelamin perempuan perempuan, $66 \%$ responden berpendidikan tinggi, 24,2 $\%$ responden adalah wiraswasta dan 43,3\% responden sudah menikah.

Pasien COVID-19 tidak mengenal batasan usia, bisa terjadi pada bayi, anak-anak, remaja, dewasa maupun lansia. Kelompok populasi yang rentan adalah bayi, balita, anak-anak dan lansia apalagi jika terdapat faktor komorbid lain seperti penyakit hipertensi dan diabetes mellitus. Kelompok usia dewasa merupakan kelompok yang paling banyak mengalami penyakit ini karena pada usia ini paling produktif dan faktor mobilisasi yang tinggi. Pada penelitian ini responden paling banyak pada usia dewasa akhir (3645). Hal ini sejalan dengan penelitian yang telah dilakukan oleh (Saqlain et al., 2020).

Pada penelitian ini mayoritas berjenis kelamin perempuan, hal ini sejalan dengan penelitian yang dilakukan di Henan, China (Zhang et al., 2020). Pendidikan responden mayotitas pendidikan tinggi sehingga hal ini yang menyebabkan bahwa tingkat pengetahuan, sikap dan keterampilan masyarakat dalam pencegahan 
COVID-19 baik. Akan tetapi masyarakat yang tingkat pendidikan rendah belum tentu pengetahuan, sikap dan keterampilannya kurang karena pada zaman ini teknologi untuk akses informasi sangat banyak. Hal ini juga sejalan dengan penelitian yang telah dilakukan di Indonesia pada 34 Provinsi (Yanti et al., 2020).

Tabel 2

Distribusi frekuensi pengetahuan, sikap dan keterampilan dalam pencegahan COVID-19 pada masa New Normal

\begin{tabular}{ccc}
\hline Variabel & $\begin{array}{c}\text { Frekuensi } \\
(\mathrm{n})\end{array}$ & $\begin{array}{c}\text { Persentase } \\
(\%)\end{array}$ \\
\hline Pengetahuan & & \\
\hline Baik & 847 & 83 \\
\hline Kurang & 174 & 17 \\
\hline Sikap & & \\
\hline Baik & 722 & 70,7 \\
\hline Kurang & 299 & 29,3 \\
\hline Keterampilan & & \\
\hline Baik & 718 & 70,3 \\
\hline Kurang & 303 & 29,7 \\
\hline
\end{tabular}

Hasil analisis deskriptif didapatkan bahwa $83 \%$ responden memiliki pengetahuan yang baik mengenai pencegahan COVID-19, 70,7\% responden memiliki sikap yang baik mengenai pencegahan COVID-19 dan $70,3 \%$ responden memiliki keterampilan yang baik mengenai pencegahan COVID-19. Hal ini sejalan dengan penelitian yang telah dilakukan di Indonesia (Yanti et al., 2020).

Pengetahuan yang dikaji adalah mengenai pemahaman akan proses penularan penyakit, informasi terkait pencegahan yang dapat dilakukan, informasi akan sebaran kasus. Pengetahuan sangat pening dalam melanjutkan aspek sikap dan perilaku karena jika seserang tidak tahu maka tidak akan ada tindakan nyata yang dilakukan. Pengetahuan masyarakat dalam mencegah transmisi penyakit akan menekan penularan COVID-19 lebih lanjut (Law, Leung, \& Xu, 2020).

Sikap yang diteliti meliputi keinginan dalam melakukan pencegahan, sikap positif terhadap relasi/keluarga/rekan yang telah terkena COVID-19. Sikap masyarakat yang baik akan dilaksanakan dengan konsisten bila ada aturan yang tegas dari pemangku kebijakan dan role model yang baik dari tokoh-tokoh publik. Sehingga penting dalam membentuk sikap masyarakat yang didukung oleh kebijakan pemerintah (Firda \& Haksama, 2020). 
Keterampilan yang diteliti adalah perilaku responden akan protokol new normal seperti konsistensi penggunaan masker, menahan diri untuk tidak keluar rumah kecuali jika terpaksa, selalu mencuci tangan dengan sabun di air mengalir, selalu menyediakan disinfektan, mandi sesegera mungkin setelah keluar dari rumah, tidak melakukan kontak fisik, menjaga jarak, membatasi jumlah penumpang dalam kendaraan, menjaga sistem kekebalan tubuh melalui asupan nutrisi yang adekuat dan olahraga rutin. Keterampilan juga meliputi secara periodik mencari informasi terkait update kasus COVID-19.

Secara umum mayoritas pengetahuan, sikap dan keterampilan masyarakat Provinsi DKI Jakarta baik dalan pencegahan COVID-19, akan tetapi masih ada sebagian kecil yang kurang baik. Sehingga pemerintah dibantu sektor lain misalnya sektor pendidikan untuk melakukan upaya-upaya promosi kesehatan Intervensi dan kampanye ditujukan untuk mempengaruhi perilaku seseorang. Intervensi didasarkan pada teori yang meningkatkan

pengetahuan masyarakat dan kesadaran akan risiko kesehatan tertentu akan menghasilkan perubahan perilaku yang positif (Andrews et al., 2020).

Pemerintah Indonesia telah mempertimbangkan dan menerapkan banyak strategi untuk mengatasi COVID-19, misalnya seperti pelacakan kontak, tes masif dan cepat, dan penyediaan kebutuhan perawatan yang memadai. Strategi lain yang digunakan adalah adanya kebijakan pada perusahaan, jika operasional perusahaan bisa dilakukan menggunakan metode work from home maka sebaiknya dilaksanakan, kecuali sektor yang tidak bisa dilaksanakan maka pimpinan sektor/ perusahaan harus menyusun aturan atau kebijakan pembatasan jumlah orang dalam suatu tempat (Setyawan \& Lestari, 2020).

Masyarakat perlu memahami bahwa saat ini rumah sakit menjadi area yang cukup berbahaya juga karena dapat menyebabkan infeksi silang antara pasien dan dokter, sehingga banyak rumah sakit telah mengambil tindakan untuk membatasi layanan 
rawat jalan, rawat inap elektif, dan jumlah operasi. Cara mencegah dan mengendalikan penularan SARSCoV-2 secara efektif sambil memberikan perawatan kepada pasien bedah selama pandemi adalah hal yang penting (Wang, Pan, Tang, Ji, \& Shi, 2020).

\section{KESIMPULAN}

Hasil penelitian ini menunjukkan bahwa $83 \%$ responden memiliki pengetahuan yang baik mengenai pencegahan COVID-19, 70,7\% responden memiliki sikap yang baik mengenai pencegahan COVID-19 dan $70,3 \%$ responden memiliki keterampilan yang baik mengenai pencegahan COVID-19, akan tetapi kasus baru COVID-19 setiap harinya bertambah sejumlah kurang lebih seribu kasus. Hal ini menunjukkan bahwa masih perlu ada upaya yang lebih dalam penanganan COVID-19 ini. Penerapan new normal harus diimbangi dengan kepatuhan yang tinggi dari masyarakat akan pencegahan COVID-19 agar tidak bertambah kasus baru. Proses Adaptasi Kebiasaan Baru (AKB) harus konsisten dilaksanakan mulai dari penggunaan masker, menjaga jarak, mencuci tangan, tidak melakukan kontak fisik, meningkatkan daya tahan tubuh melalui asupan nutrisi dan olahraga.

\section{DAFTAR PUSTAKA}

Andrews, J. L., Foulkes, L., \& Blakemore, S. J. (2020). Peer Influence in Adolescence: Public-Health Implications for COVID-19. Trends in Cognitive Sciences, 24(8), 585-587. https://doi.org/10.1016/j.tics.20 20.05.001

Farizi, S. Al, \& Harmawan, B. N. (2020). Data Transparency and Information Sharing:

Coronavirus Prevention

Problems in Indonesia. Jurnal Administrasi Kesehatan Indonesia, $\quad 8(2), \quad 35$. https://doi.org/10.20473/jaki.v8i 2.2020.35-50

Firda, A. A., \& Haksama, S. (2020). Building Health System Resilience During Covid-19 Crisis. Jurnal Administrasi Kesehatan Indonesia, 8(2), 1. https://doi.org/10.20473/jaki.v8i 2.2020.1-3 
Law, S., Leung, A. W., \& Xu, C. (2020). Severe acute respiratory syndrome (SARS) and coronavirus disease-2019 (COVID-19): From causes to preventions in Hong Kong. International Journal of Infectious Diseases, 94, 156163.

https://doi.org/10.1016/j.ijid.202 0.03 .059

Liu, F., Wang, W., Yu, H., Wang, Y., Wu, W., Qin, X., \& Zhao, Y. (2020). Surgery in Practice and Science Prevention and control strategies of general surgeons under COVID-19 pandemic. Surgery in Practice and Science, 1(April), 100008. https://doi.org/10.1016/j.sipas.2 020.100008

Mansuri, F. M. A., Zalat, M. M., Khan, A. A., Alsaedi, E. Q., \& Ibrahim, H. M. (2020). Estimating the public response to mitigation measures and selfperceived behaviours towards the COVID-19 pandemic. Journal of Taibah University Medical Sciences, (xxxx). https://doi.org/10.1016/j.jtumed. 2020.06 .003
Saqlain, M., Munir, M. M., Rehman, S. U., Gulzar, A., Naz, S., Ahmed, Z., ... Mashhood, M. (2020). Knowledge, attitude, practice and perceived barriers among healthcare workers regarding COVID-19: a crosssectional survey from Pakistan. Journal of Hospital Infection, 105(3), 419-423. https://doi.org/10.1016/j.jhin.20 20.05.007

Setyawan, F. E. B., \& Lestari, R. (2020). Challenges of Stay-AtHome Policy Implementation During the Coronavirus (Covid19) Pandemic in Indonesia. Jurnal Administrasi Kesehatan Indonesia, $\quad 8(2), \quad 15$. https://doi.org/10.20473/jaki.v8i 2.2020.15-20

Suryaatmadja, S., \& Maulani, N. (2020). Contributions of Space Technology To Global Health in the Context of Covid-19. Jurnal Administrasi Kesehatan Indonesia, $\quad 8(2), \quad 60$. https://doi.org/10.20473/jaki.v8i 2.2020.60-73

Wang, J., Pan, L., Tang, S., Ji, J. S., \& Shi, X. (2020). Mask use during COVID-19: A risk 
adjusted

strategy.

Administrasi

Kesehatan

Environmental

Pollution,

Indonesia,

$8(2)$,

4.

266(7),

115099.

https://doi.org/10.20473/jaki.v8i

https://doi.org/10.1016/j.envpol.

2.2020.4-14

2020.115099

Zhang, M., Zhou, M., Tang, F.,

Yanti, B., Wahyudi, E., Wahiduddin, Wang, Y., Nie, H., Zhang, L., \& W., Novika, R. G. H., Arina, Y. You, G. (2020). Knowledge, M. D., Martani, N. S., \& attitude, and practice regarding Nawan, N. (2020). Community

Knowledge, Attitudes, and

Behavior Towards Social

Distancing Policy As

Prevention Transmission of

Covid-19 in Indonesia. Jurnal COVID-19 among healthcare workers in Henan, China. Journal of Hospital Infection, 105(2), 183-187. https://doi.org/10.1016/j.jhin.20 20.04.012 